\title{
Effect of the EM Immobilized Technology on Nitrogen Dissolution Characteristics of Aquaculture Sediment
}

\author{
Long WANG ${ }^{1,2}$, Ya-Lu SHAO ${ }^{1}$, Xin-Yu MAO ${ }^{1,3}$, Xiao-Hou SHAO ${ }^{2,3}$, Qi-Jin WU ${ }^{4}$ \\ ${ }^{1}$ College of Water Conservancy and Hydropower Engineering, Hohai University, Nanjing, 210098, \\ China \\ ${ }^{2}$ Key Laboratory of Efficient Irrigation-Drainage and Agricultural Soil-Water Environment in Southern \\ China of Ministry of Education, Hohai University, 210098, China \\ ${ }^{3}$ Nanjing Ning-ya Environmental Science and Technology Limited Company, Nanjing 210036, PR \\ China \\ ${ }^{4}$ Gaochun Water Conservancy Bureau, Nanjing, 211300, China \\ wlong204@163.com
}

Keywords: EM nano-silica ball, aquaculture sediment, the inorganic nitrogen dissolution characteristics, inhibitory effect.

\begin{abstract}
Effect of nitrogen dissolution characteristics of pond sediment by the immobilized EM technology was studied by the indoor simulation experiments in this paper. The results showed that ammonia nitrogen was the main forms of inorganic nitrogen dissolved from the sediment. The release of ammonia nitrogen from the sediment was related to the $\mathrm{pH}$ of the aquaculture wastewater. The ammonia nitrogen was escaped from the water with the higher value of $\mathrm{pH}$ and the concentration of ammonia nitrogen in water would be reduced. Applying microbial nano-silica balls would inhibit the release of inorganic nitrogen effectively from the sediments to the water and reduce the content of total nitrogen and ammonia nitrogen in aquaculture water. The dissolution amount of inorganic nitrogen was not related with the thickness of sediment for the treatment of $\mathrm{CK}$, but it was faster in the early period with the thicker sediment. However, the inhibiting effect of inorganic nitrogen dissolution was reduced when the sediment was thicker for the treatment of EM nano-silica ball.
\end{abstract}

\section{Introduction}

In recent years, aquaculture production in China has accounted for about $2 / 3$ in the world with the rapid development of intensive aquaculture [1]. Eutrophication phenomenon and water pollution caused by aquaculture were more and more serious due to the residual feed and excrement of fish, shrimp and crab in water ponds [2-3]. Pollutants accumulated in sediment would released into the overlying water and make the waters secondary pollution [4].

The high efficient microbial agent has been widely concerned in the field of agricultural production and wastewater treatment. The application of immobilized microbial technology has been gaining more and more importance for repairing the ecosystems of aquaculture wastewater. The immobilized microbial technology has the advantages of easy control of biological concentration, strong poison -resistant ability, high cell density, rapid response, small species loss, easy product separation, etc [5]. It has good effect in the treatment of surface water [6], sanitary sewage [7] and aquaculture wastewater [8].

The immobilized microorganism technology was successfully used to sediment ecological restoration at overseas [9],but the research and application about the immobilized microorganism technology used to recover the ecosystem of sediment was almost blank in China. The effect of nitrogen dissolution characteristics in sediment by the EM nano-silica ball was studied by using indoor simulation study in order to provide theoretical and experimental basis of the immobilized EM technology for the purification of aquaculture water. 


\section{Materials and Methods}

\section{Materials}

Nano-Silica was purchased from Shanghai DiKe Industrial Co.LTD, zeolite powder was directly bought on TaoBao, EM bacteria liquids and molasses were purchased from EMRO (Nanjing) Co.LTD.

\section{Fermentation Production of EM Active Calcium}

EM active calcium was fermented by Effective Microorganisms (EM), molasses, deionized water and $2 \%$ calcium-containing substances [10]. The proportion of different materials in fermentation of EM active calcium was presented in Table 1. The materials for EM active calcium production were fermented by thermostatic shaking (QHZ-98A) under the condition of $37^{\circ} \mathrm{C}$ and $150 \mathrm{r} / \mathrm{min}$.

Tab. 1 Proportion of different materials in fermentation of EM active calcium

\begin{tabular}{|c|c|c|c|c|}
\hline $\begin{array}{c}2 \% \mathrm{Ca}^{2+} \text { suspending liquid } \\
(\mathrm{ml})\end{array}$ & $\begin{array}{c}\text { EM } \\
(\mathrm{ml})\end{array}$ & $\begin{array}{c}\text { Molasses } \\
(\mathrm{ml})\end{array}$ & $\begin{array}{c}\text { Deionized water } \\
(\mathrm{ml})\end{array}$ & $\begin{array}{c}\text { The calcium content } \\
(\%)\end{array}$ \\
\hline 18.0 & 9.0 & 9.0 & 24.0 & 0.6 \\
\hline
\end{tabular}

\section{Preparation of Nano-silica Carrier and Microbial Nano Ball}

Firstly, 10\% nano-silica, 10\% zeolite powder and 80\% aquiculture pond sediment were mixed. Then the mixture was soaked in EM active calcium for 2 days. After that, the mixture was put into the granulator granulation in order to get a $20-30 \mathrm{~mm}$ diameter spherical carrier. Finally, the spherical carrier was dried at about $250^{\circ} \mathrm{C}$. The nano-silica carrier was soaked in EM active calcium for 2 days, and then was taken out and placed at room temperature for 2 days. The preparation of microbial nano balls was finished (the weighing was about $10 \mathrm{~g}$ and the adsorption quantity of EM activated calcium was about $5 \mathrm{ml})$.

\section{Sample Collection and Preparation}

The test sediment was collected in the aquaculture pond at stone village located in HengXi town, Jiangning District,Nanjing after the pond was cleared and drained in the winter. The samples were collected on the surface of $0 \sim 10 \mathrm{~cm}$ and put into plastic containers with Grab borrow devices. The excess water, shellfish, twigs and other larger objects were removed. The sediment was taken back to stand in ventilated place to prevent pollution and used for simulation test when it was natural dry grinding to pass 10-mesh sieve. Background values of the sediment were shown as in Table 2.

Tab. 2 The background value of the sediment

\begin{tabular}{|c|c|c|c|}
\hline $\begin{array}{c}\text { Measurement } \\
\text { indicators }\end{array}$ & $\begin{array}{c}\text { organic matter } \\
(\mathrm{g} / \mathrm{kg})\end{array}$ & $\begin{array}{c}\text { total nitrogen } \\
(\mathrm{g} / \mathrm{kg})\end{array}$ & $\begin{array}{c}\text { alkaline hydrolysis nitrogen } \\
(\mathrm{mg} / \mathrm{kg})\end{array}$ \\
\hline concentration & 259.04 & 17.43 & 329.43 \\
\hline
\end{tabular}

\section{Experimental Designs}

First, sediment bulk density was taken as $1.25 \mathrm{~g} / \mathrm{cm} 3$. According to the designed sediment thickness, the dried sediment samples were weighed as $1227 \mathrm{~g}(2 \mathrm{~cm}), 3068 \mathrm{~g}(5 \mathrm{~cm})$ and $6136 \mathrm{~g}(10 \mathrm{~cm})$, and loaded into a plastic pail container respectively. The deionized water was slowly added to the treatment group along the plastic pail container wall to avoid stirring the sediment surface. When the water layer overlaid a height of $15 \mathrm{~cm}$, there was $10594 \mathrm{~mL}$ of water for each treatment group. The treatment of CK which was as a blank and the treatment of EM which was put into $20 \mathrm{~g}$ of microbial nano balls were set up, each with three replicates in a randomized complete design. Under the static condition indoors, the upper $200 \mathrm{~mL}$ water samples was taken for analysis and the $\mathrm{pH}, \mathrm{NH}_{4}{ }^{+}-\mathrm{N}, \mathrm{TN}$, $\mathrm{NO}_{3}{ }^{-} \mathrm{N}$ and $\mathrm{NO}_{2}{ }^{-}-\mathrm{N}$ values were tested for the $2,4,6,9,12,15,19,23,31$ day after the reaction. The deionized water was added to keep the height of $10 \mathrm{~cm}$ for each treatment. 


\section{Testing Methods}

$\mathrm{NH}_{4}{ }^{+}-\mathrm{N}$ was measured by the Nessler reagent spectrophotometry, TN was measured by the Potassium persulfate digestion of ultraviolet spectrophotometry, $\mathrm{NO}_{3}{ }^{-}-\mathrm{N}$ was measured by the ultraviolet spectroscopy, $\mathrm{NO}_{2}^{-}-\mathrm{N}$ was measured by the $\mathrm{N}$-(1-naphthyl)- ethylenediamine spectrophotometry, $\mathrm{pH}$ was measured by the $\mathrm{pH}$ meter.

\section{Calculation}

According to the concentration of each water quality index for each measured value, the total amount of sediment nutrient of the treatment dissolved out to the overlying water with the following formula in different period.

$$
\mathrm{Mi}=\mathrm{Ci} \times 2686+(\mathrm{C} 1+\mathrm{C} 2+\ldots \mathrm{Ci}-1) \times 200
$$

where, $\mathrm{M}$ was the dissolution for the total nutrients (ug), $\mathrm{C}$ was the nutrient concentration in the water $(u \mathrm{~g} / \mathrm{mL})$, I was the number of sampling times $(\mathrm{i}=1,2, \ldots, 9)$.

\section{Results and Analysis}

\section{Effect of the EM Immobilized Technology on $\mathrm{NH}_{4}{ }^{+}-\mathrm{N}$ Dissolution Characteristic}

From figure 1, it could be seen that dissolution characteristics of $\mathrm{NH}_{4}{ }^{+}-\mathrm{N}$ in sediments under different treatment was quite different. Dissolution rate and content of $\mathrm{NH}_{4}{ }^{+}-\mathrm{N}$ dissolved from the sediment of the CK groups were higher than the EM groups. The $\mathrm{NH}_{4}{ }^{+}-\mathrm{N}$ content of each group increased sharply, but the rate of each group of $\mathrm{EM}$ in $\mathrm{NH}_{4}{ }^{+}-\mathrm{N}$ content increasing was lower than that of $\mathrm{CK}$ in the first nine days after the treatment was set. The amount of $\mathrm{NH}_{4}{ }^{+}-\mathrm{N}$ tended to rise in each treatment group until the end of the test, but the concentration of $\mathrm{NH}_{4}{ }^{+}-\mathrm{N}$ in EM group reduced compared with that of CK group. And the dissolution of total nitrogen was decreased by $30.1 \%$ in $5 \mathrm{~cm}$ group respectively.

These results showed that dissolution rate and content of $\mathrm{NH}_{4}{ }^{+}-\mathrm{N}$ dissolved from the sediment of the EM groups were lower than those of CK groups. Because the EM bacteria had just entered the aquaculture wastewater and Microbial Nano-Silica Balls basically did not inhibit the dissolution of $\mathrm{NH}_{4}{ }^{+}-\mathrm{N}$ from the sediment in six days after the test. With the adaptation of EM bacteria to water environment, the nitrification was conducted to promote the mycelium of ammonifying bacteria to consume oxygen which $\mathrm{NH}_{4}{ }^{+}-\mathrm{N}$ could be converted to $\mathrm{NO}_{3}^{-}-\mathrm{N}$ and $\mathrm{NO}_{2}^{-}-\mathrm{N}$. Finally, the denitrification made the nitrate become the $\mathrm{N}_{2}$ gas to escape into the atmosphere so that the content of $\mathrm{NH}_{4}{ }^{+}-\mathrm{N}$ could be reduced. With $5 \mathrm{~cm}$ or smaller sediment thickness, EM bacteria had more pronounced effect to inhibit the dissolution of $\mathrm{NH}_{4}{ }^{+}-\mathrm{N}$. When the sediment thickness was $10 \mathrm{~cm}$ or more, the effect to inhibit the dissolution of $\mathrm{NH}_{4}{ }^{+}-\mathrm{N}$ would be reduced, suggesting the more Microbial Nano-Silica Balls were needed
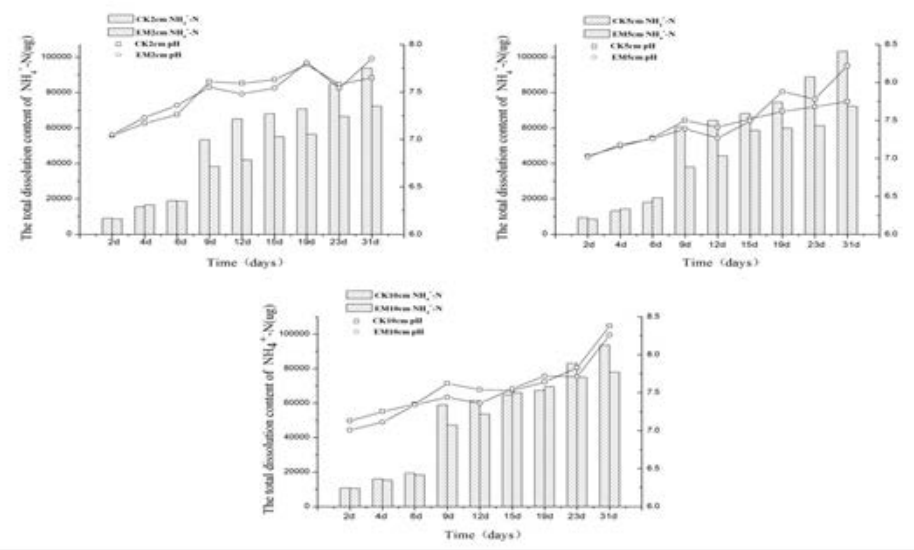

Fig.1 The $\mathrm{NH}_{4}{ }^{+}-\mathrm{N}$ content of each treatment group [ug] 


\section{Effect of the EM Immobilized Technology on $\mathrm{NO}_{3}{ }^{-}-\mathrm{N}$ Dissolution Characteristic}

From figure 2, it could be seen that dissolution characteristics of $\mathrm{NO}_{3}{ }^{-}-\mathrm{N}$ in sediments under different treatment was quite different. Total dissolution of $\mathrm{NO}_{3}{ }^{-} \mathrm{N}$ in sediments peaked in second day, and then reduced gradually until on the nineteenth day and achieved the minimum, only slightly picked up by the end of the test on the whole process. The total dissolution of $\mathrm{NO}_{3}{ }^{-}-\mathrm{N}$ of the EM group was much the same of the CK group in the first nine days after the treatment was set. But a sharp downward trend was shown on the twelfth day, and the total amount of the final dissolution of $\mathrm{NO}_{3}{ }^{-}-\mathrm{N}$ in EM group was less than that of $\mathrm{CK}$ group. Although the $\mathrm{NO}_{3}{ }^{-}-\mathrm{N}$ decreased in EM group was not obvious compared with the $\mathrm{CK}$ group, the total $\mathrm{NO}_{3}{ }^{-}-\mathrm{N}$ in EM group was reduced faster than that of CK group in the process of test.

These results suggested that the dissolution of $\mathrm{NO}_{3}{ }^{-} \mathrm{N}$ mainly occurred in the early stage of the experiment and the dissolution amount of $\mathrm{NO}_{3}{ }^{-} \mathrm{N}$ had nothing to do with the thickness of sediment. In addition, the EM group could quickly reduce the dissolution amount of $\mathrm{NO}_{3}{ }^{-}-\mathrm{N}$ in water than the CK group.

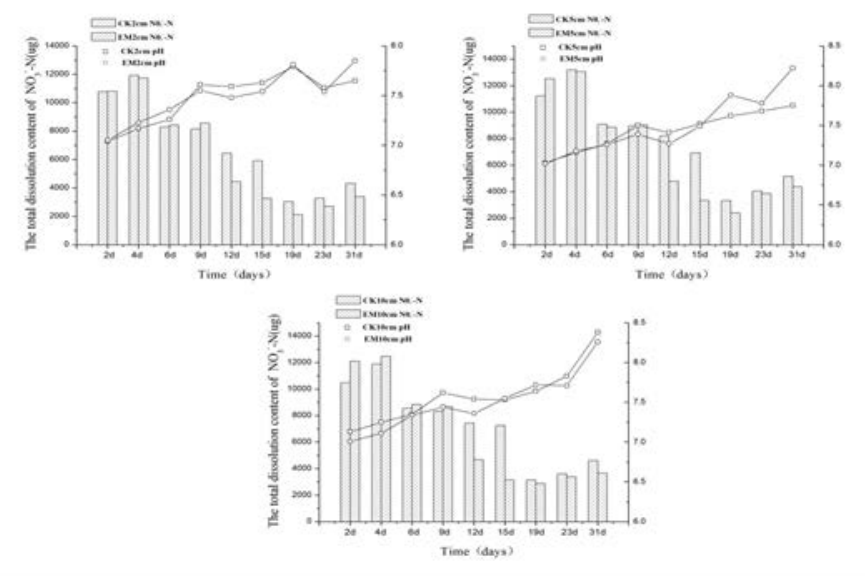

Fig. 2 The $\mathrm{NO}_{3}{ }^{-}-\mathrm{N}$ content of each treatment group [ug]

\section{Effect of the EM Immobilized Technology on $\mathrm{NO}_{2}{ }^{-}-\mathrm{N}$ Dissolution Characteristic}

From figure 3, it could be seen that dissolution characteristics of $\mathrm{NO}_{2}{ }^{-} \mathrm{N}$ in sediments under different treatment was quite different. The dissolution of $\mathrm{NO}_{2}{ }^{-}-\mathrm{N}$ was obviously detected until on the nineteenth day in this experiment. It had to do with higher $\mathrm{pH}$, dissolved oxygen changes and transformation of various forms of nitrogen in the system. The $\mathrm{NO}_{2}^{-}-\mathrm{N}$ concentration of $10 \mathrm{~cm}$ group was eventually detected highest in EM group, however, it was highest in $5 \mathrm{~cm}$ group for $\mathrm{CK}$. The $\mathrm{NO}_{2}{ }^{-}-\mathrm{N}$ content of EM groups was higher than that of CK groups in general. But the CK group had the higher content of $\mathrm{NO}_{2}^{-}-\mathrm{N}$ than EM group for $5 \mathrm{~cm}$ sediment thickness.

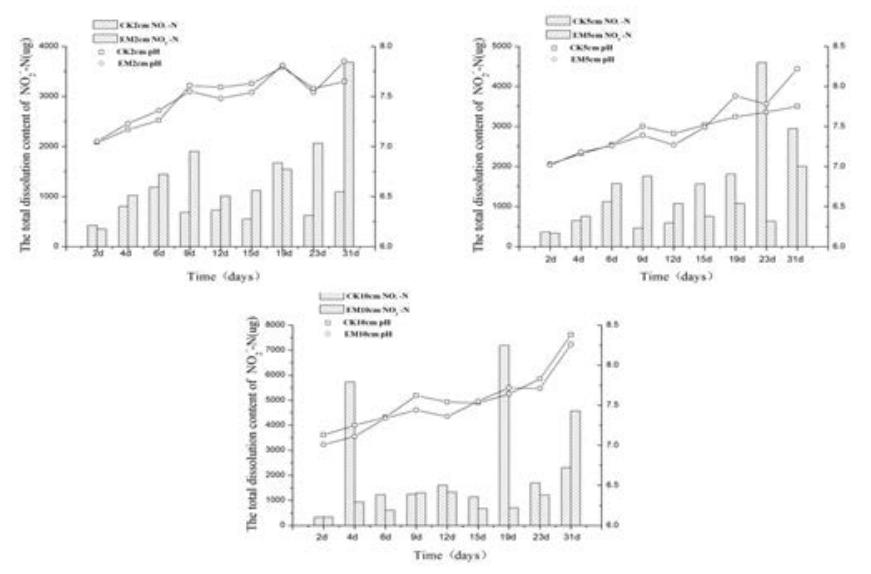

Fig. 3 The $\mathrm{NO}_{2}{ }^{-}-\mathrm{N}$ content of each treatment group [ug] 
These results suggested that a lower sediment thickness was more conducive to nitrite presence of the water system in EM groups and it was the opposite for CK groups. Under the experimental condition, inorganic nitrogen releasing into the overlying water existed in the form of $\mathrm{NH}_{4}^{+}-\mathrm{N}$ at first, and quickly transformed into $\mathrm{NO}_{2}^{-}-\mathrm{N}$, then changed to $\mathrm{NO}_{3}^{-}{ }^{-} \mathrm{N}$. $\mathrm{NO}_{2}{ }^{-}-\mathrm{N}$ was an intermediate morphological change of inorganic nitrogen forms, and was a transitional form in denitrification. In this study, the index of $\mathrm{NO}_{2}^{-}-\mathrm{N}$ showed a trend of instability, which tended to be consistent with previous findings [11].

\section{Inorganic Nitrogen Dissolution Characteristics with the Different Sediment Thickness}

The total dissolution of ammonium and nitrate for each CK treatment group was essentially the same with no significant difference. The total dissolution content of ammonia, nitrate and nitrite nitrogen at each EM treatment in $2 \mathrm{~cm}$ and $5 \mathrm{~cm}$ groups was less than that in $10 \mathrm{~cm}$ group, indicating that the inhibiting effect was reduced when the sediment was thicker in the treatment of EM.

These results suggested that amount of inorganic nitrogen released at EM groups was down compared with that of CK groups, indicating that Microbial Nano-Silica balls used could inhibit the release of inorganic nitrogen effectively from the sediments to the water and the immobilized EM technology could reduce the content of total nitrogen in water. The dissolution of total nitrogen amount was related to the thickness of sediment in the treatment of EM. And it had nothing to do with the thickness of sediment in the treatment of CK.

\section{Conclusions and Discussion}

The released inorganic nitrogen was mainly composed of ammonia nitrogen in the sediment, and its release was dependent on $\mathrm{pH}$ value, the $\mathrm{DO}$, organic matter and so on. The $\mathrm{H}^{+}$concentration was high with a low $\mathrm{pH}$ value, and $\mathrm{NH}_{4}{ }^{+}$absorbed by colloidal sediment was released, and the concentration of the aqueous solution of ammonia increased correspondingly. With high $\mathrm{pH}$ in aqueous solution, $\mathrm{NH}_{4}{ }^{+}$released from the colloid sediment produced chemical reaction with $\mathrm{OH}^{-}$ions which made the $\mathrm{NH}_{4}{ }^{+}$escape from aqueous solution in the form of $\mathrm{NH}_{3}$. The higher concentration of $\mathrm{OH}^{-}$caused $\mathrm{NH}_{4}{ }^{+}$escaped from the water in the form of $\mathrm{NH}_{3}$ and the concentration of $\mathrm{NH}_{4}{ }^{+}$in water reduced [12]. The total dissolution of inorganic nitrogen had nothing to do with the sediment thickness at CK group, but it was faster at the early stage of treatment in thicker sediment. And inhibiting effect of EM group was reduced for thicker sediment during early stage of treatment. Under the static condition, the release of nutrient in sediment could only through the natural formation of the concentration gradient upward to overlying water [13]. But the release of nitrogen mainly depended on the degree of decomposition of nitrogen compounds [14]. And there was no direct relationship with the sediment thickness. But the thicker sediment made the aquaculture water quality fecund, so that the $\mathrm{pH}$ of water was reduced and the oxygen consumption was increased. And the purification of the EM bacteria weakened with long-term lower hypoxia in the water.

Microbial Nano-Silica balls could inhibit the release of inorganic nitrogen effectively from the sediments to the water which suggested the immobilized EM technology could reduce the content of nitrogen and other pollutants in water. When the EM bacteria had just entered the aquaculture wastewater, the ammoniation decomposed nitrogenous organic matter in the sediment and inorganic nitrogen was released into the water in the form of ammonium, so the $\mathrm{NH}_{4}{ }^{+} \mathrm{N}$ and total nitrogen concentration were increased in the water. With the adaptation of EM bacteria to water environment, the nitrification promoted the mycelium of ammonifying bacteria to consume oxygen which $\mathrm{NH}_{4}{ }^{+}-\mathrm{N}$ could be converted to $\mathrm{NO}_{3}{ }^{-}-\mathrm{N}$ and $\mathrm{NO}_{2}{ }^{-}-\mathrm{N}$. Finally, the denitrification made the nitrate become the nitrogen gas to escape into the atmosphere so that $\mathrm{NH}_{4}{ }^{+}-\mathrm{N}$ and total nitrogen could be reduced. EM active calcium fixed in the carrier which sediment was as main component could not only greatly increase the concentration and quantity of micro-organism, but also improve the activity of microbes. It would be effective to quickly adapt to the environment of aquaculture wastewater and play degradation effect on water pollution material. In addition, solid preparation could sink into the aquaculture wastewater bottom and make some microbes into the sediment to inhibit the release of sediment nutrients. By adding the fine decontamination ability of microorganism immobilized by the 
carrier to the sediment surface, it could effectively resist the change of natural environment and have the obvious superiority.

\section{Acknowledgements}

This work was financially supported by the Fundamental Research Funds for the Central Universities(2014B04814), the National Natural Science Foundation of China (51179054), the Water Science and Technology Project of Jiangsu Province (2014049), the State Experiment Teaching Demonstration Centre of Water Conservancy Discipline (Hohai Uni).

\section{References}

[1]Xiuzhen Zhao,Daofu Han,Shuguang Sun, et al. Present situation and Countermeasures of prevention and control of pollution source of aquaculture[J]. Shandong Fisheries, 2008, 25(5): 66-67. In Chinese.

[2]JunYing Wang, et al.Control measures of ecological environment pollution in aquaculture[J]. Jourrnal of BeiJing Fisheries, 2004, 4: 4-6. In Chinese.

[3]Ying Cui, Weiling Zang, et al. Relationship between Aquaculture and FisheryAqueous Environment Modern[J]. Fisheries Information,2006, 4: 10-11. In Chinese.

[4]Wenquan Yuan, et al. Study on the Internal Pollution in Xili Reservoir and Its Control[D]. Peking University,2004. In Chinese.

[5]Jing Li, et al. Removal of Pyrene by Immobilized Microorganism Using Preadsorption on corn stalk-embedding-crosslinking Immobilization method[J]. South China University of Technology, 2012. In Chinese.

[6]Xiaona Wei, Gang Li, Bo Wu, et al. Using immobilized microorganism to treat synthetic polluted surface water[J]. Chinese Journal of Ecology, 2012, 31(007): 1882-1886. In Chinese.

[7]Yunhai Wu, Yunying Wu, Yue Wu. Study on Treatment of Sewage with Immobilized Microorganism[J]. Journal of Anhui Agricultural Science, 2010, 38(5): 2496-2497. In Chinese.

[8]Xujie Lu, Shili Zhou, Qiongyu Liu, et al. Research progress of Immobilized microorganism technology on aquaculture water denitrification[J]. Environmental Protection and Circular Economy, 2012, 26(4): 8-11. In Chinese.

[9]Yingying Li. The experimental study on the sediment remediation by immobilized microorganisms[D]. Huazhong University of Science and Technology, 2009. In Chinese.

[10]Chen JN, Shao XH, Chang TT, et al, Fermentation Production of EM Active Calcium and its Performance for the Prevention on Blossom-End Rot in Facility Tomato Cultivation[J]. Advanced Materials Research, 610, pp.138-143, 2013.

[11]Min Jiang, Guowei Gu,Yongmei Li. Impact of Aquaculture on the Environment in China and Countermeasures[J]. Chongqing Environment Sciences, 2003,25(5):11-12. In Chinese.

[12]Garban B,Ollivon D,Roulin M,et al.Exchanges at the sediment-water interface in the river seine, downstream from Paris. Water Research. 1995.

[13]Sun Yao, Songyun Li. Feature and behavior of nitrogen and phosphorous nutrents in shrimp ponds[J]. Journal of Fisheries of China, 1998,22(2):121-122. In Chinese.

[14]Sun Y, Zhao J. Contamination of Shrimp Ponds with Organic Matter in Peanuts Chinese Culture and some Associated Problems[C]. In proceedin gs on international symposium on shrimp culture in Asia-Pacific region. 1993, 151-154. 